\title{
Water Resources and Management System of the Himalayan Region: Case Study of Mizoram, India
}

\author{
Brototi Biswas $\dagger$ and Abinada Azyu \\ Department of Geography \& RM, Mizoram (Central) University, Aizawl, Mizoram, India \\ $\dagger$ Corresponding author: Brototi Biswas; brototibiswas@gmail.com
}

Nat. Env. \& Poll. Tech.

Website: www.neptjournal.com

Received: 12-08-2020

Revised: $18-09-2020$

Accepted: 15-10-2020

\section{Key Words:}

Water resources

Water management

Sustainability

Himalayas

\begin{abstract}
The Himalayan region has been known as water abundant region in the form of innumerable natural water resources such as springs, streams, rivulets, etc. However, off late owing to climatic and anthropogenic reasons the entire region is soon turning into a water-deficit region leading to serious handicaps in undertaking the basic economic activities, affecting the diversity of livelihood and the drinking water sector. The problem becomes more acute in the dry season or non-monsoonal season. There seems to be a research void in the sustainable water resource planning of the Himalayan states. The present work is an attempt to study this research void through grass-root level analysis of the villages in Mizoram. Twelve villages of the Phullen RD block of Aizawl district, Mizoram were studied to understand the water supply and problems associated with water availability in the rural areas of Mizoram. In the villages of Mizoram, particularly the villages of the study area, Tuikhur or village spring source (VSS) and piped water supply constitute the main lifeline of water supply. Other sources of water include rainwater harvested and water taken from the stream or river. The springs which were once perennial have become seasonal owing to lack of spring shed management. Rainwater harvesting, barring inconsequential villages, is meagrely existent in this region of abundant rainfall with almost 130 days of rainfall. In the absence of proper water resource planning, there is a huge deficit of water every month with the average requirement of the study area being 2,49,148 gallons per month with a supply of just 2,14,248 gallons per month. However, water surplus was also observed in villages having a proper water management system in the form of rainwater harvesting and spring shed management.
\end{abstract}

\section{INTRODUCTION}

The Himalayan region, the source of innumerable water resources, is facing the problem of scarcity among plenty with an increased paucity of water owing to environmental and anthropogenic reasons. The countries in this region are facing newer and tougher challenges in meeting the basic requirement of water, food, and energy owing to rapid population rise and its associated phenomenon (Banerjee et al. 2015, Mukherji et al. 2015). With rising instances of human intervention in the natural environment, the various environmental cycles, particularly the hydrological cycle is getting affected (Biswas et al. 2019). To add to the woe, climate change, recent trends of rainfall vagaries, the geological structure of the aquifers, etc. have resulted in declining water availability in the many streams, springs, and rivers of this region (MoWR 2012, Gupta \& Kulkarni 2018). Many such water resources of this region have lost their perennial characteristics. This has led to acute water shortages in almost all the cities and towns of the Himalayan region. The worst affected seems to be the rural regions where access to potable water is a constraint from both physical and economical point of view. Reduction in water availability is a major constraint for crop production, hydropower generation, and maintaining food security across the world (Magadza 2000). Thus, it is imperative to assess the socio-economic vulnerability linked to water shortage and livelihood diversification (O'Brien et al. 2004, Huq et al. 2015, Kinouchi et al. 2019, Kuchimanchi et al. 2019, Ramprasad 2018). In a report to the NITI Ayog et al. (2018) stated that almost half of the perennial springs in the Himalayan region have lost their perennial nature and have become seasonal. Severe water shortage has been reported from various regions like Kathmandu in Nepal, Darjeeling, Mussoorie, and Shimla in India, Thimphu in Bhutan and Kabul in Afghanistan (Snyder 2014). The National Water Policy of India (NWP) was adopted in 1987 and subsequently revised in 2002 and 2012 (MoWR 2002, Kumar 2017). However the same failed to address the deteriorating water reserves and supply primarily for the hilly regions. The potential of the innumerable springs in the Himalayan states for quenching the thirst of the region has been widely acknowledged. At present, the GOI through NITI Ayog has been emphasizing rejuvenation and recharge of these springs to bring about water sustainability. Spring 
shed management has been actively taken up by Sikkim through the initiative Dhara Vikas which is led by Rural Management and Development Department (RMDD) and other stakeholders utilizing the rainfall-runoff to recharge the spring sheds, thereby increasing the spring discharge and making them perennial. Such initiative through various NGOs is also seen in Uttarakhand where various springs have been rejuvenated and have regained their perennial status.

North-eastern India, especially the Himalayan state of Mizoram, comes under tropical monsoonal climate owing to which it receives ample rainfall. Further owing to its mountainous terrain, the region is blessed with numerous springs, streams, and rivers. Thus water was never a problem. However, in recent years, the acute shortage of water, particularly in the non-monsoonal season, is witnessed not only in the urban areas but also the rural areas with the drying up of a majority of water sources. Although schemes and initiatives like Dhara Vikas have already reached various Himalayan states of Himachal Pradesh, Nagaland, and Uttarakhand, the same is yet to be seen in Mizoram. There seems to be a research void in the socio-ecological situation of the region and an appraisal of the most important resource of humanity in this region of affluence. The present work is an attempt to study this research void through grass-root level analysis of the villages of Mizoram. 12 villages of the Phullen RD block of Aizawl district, Mizoram were studied to understand the water supply and problems associated with water availability in the rural sector of Mizoram. The main objective of such study is to understand and identify the socio-ecological gaps, identify ways and means for better governance of water resources and encourage the policymakers for a conservational and sustainable development approach of water resources particularly in the rural regions of Mizoram where most of the inhabitants do not possess access to the potable water supply. Further, once the rural belt is made sustainable, the urban regions will also be benefitted.

\section{STUDY AREA}

The study was conducted for the entire Phullen RD block of Aizawl district, Mizoram enclosed within 23 $81^{\prime} 80^{\prime \prime}$ $\mathrm{N}$ and $24^{\circ} 06^{\prime} 89^{\prime \prime} \mathrm{N}$ and $93^{\circ} 01^{\prime} 38^{\prime \prime} \mathrm{E}$ and $93^{\circ} 14^{\prime} 57^{\prime \prime} \mathrm{E}$ as represented in Fig. 1. The block is constituted of 12 villages namely Daido, Khawlian, Lamherh, Luangpawn, Tlangnuam, Khawlek, Phuaibuang, Phullen, Suangpuilawn, Thanglailung, Vanbawng and Zawngin. All the 12 villages are part of this research work. Phullen block, having a total area of 515 $\mathrm{km}^{2}$ is situated in the north-east part of Aizawl district where it shares state boundary with Manipur and district boundary with Champhai in the East. Phullen RD block is surrounded by Ngopa RD block in the east situated in Champhai district, Thingsulthliah RD block of Aizawl district in the south, and

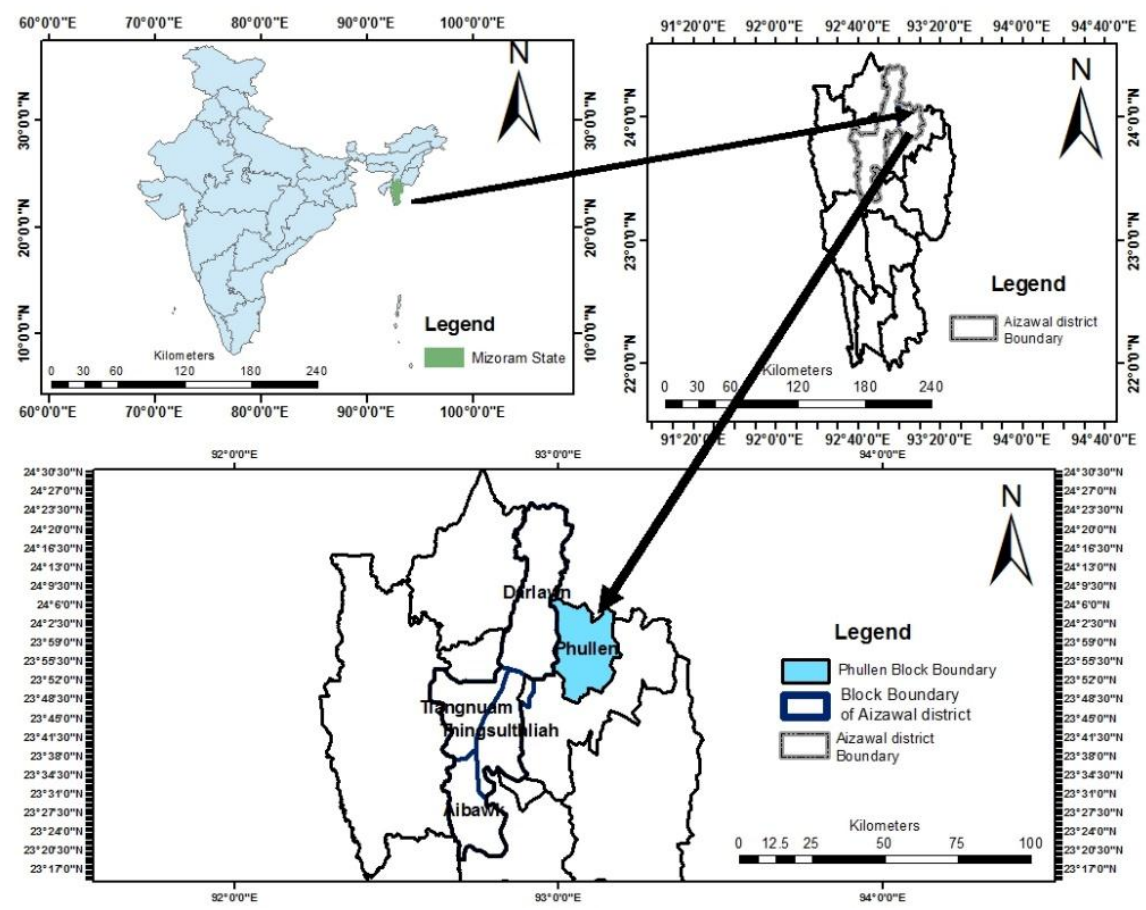

Fig. 1: Area of the study. 
Darlawn RD block of Aizawl district in the west. The study area has a population of 13,303 according to the 2011 census. The elevation ranges between 269 MSL (Thanglailung) to 422 MSL (Phuaibuang). The literacy level of the study area is more than $90.73 \%$. About $85 \%$ of the total population of the block is engaged in agriculture or related primary sector according to census 2011 data. Agriculture is primarily in the form of Jhum.

This mountain terrain, extending from north to south direction, is composed of predominantly sandstone and shale of the late tertiary period. The region has medium dense forest cover with the majority of the vegetation being of Bamboo variety which also serves as a resource for Mizoram. The climate is tropical monsoonal with a moderate climate throughout the year. Summer temperature ranges between $20^{\circ} \mathrm{C}$ to $29^{\circ} \mathrm{C}$ (March to May) while the winter temperature ranges between $7^{\circ} \mathrm{C}$ to $22^{\circ} \mathrm{C}$ (November to February). The region is under the influence of southwest monsoonal winds for the greater part of the year with an annual average rainfall ranging between $250 \mathrm{~cm}$ to $270 \mathrm{~cm}$. Phullen block has two perennial rivers, Tuivawl and Tuivai. The rivers flow through the study area in a general south-north direction. Both the rivers are joined by several streams and rivulets both perennial and non-perennial. Every village has springs, locally termed as Tuikhurs, indicating that the region has good water potential.

\section{MATERIALS AND METHODS}

Qualitative and quantitative methodologies of a questionnaire survey and data analysis were carried out. Since the objective involves water resources, it was done through field observation, Google earth, and other android based processes like Geotagging through a mobile device.

At the onset, the various sources of water supply for each of the villages of the study area were investigated, followed by a questionnaire survey of the number of households that depend on various types of water resources, daily seasonal consumption of water per household in each village, water availability from various sources per month and the material used for collecting and storing of water.

Secondly, based on the demand and supply of water from the various sources statistical analysis was done on the constraints of sustainable livelihood maintenance through SPSS software and MS Excel. The analysis has been represented through tables and graphs.

The respondents of the survey ranged from the villagers, Village council president, BDO office of Phullen block and PHED (Public Health Engineering Department) officials. The respondents were categorized according to age and sex. A total of 100 respondents from each village were surveyed which included 50 males and 50 females. $50 \%$ of the respondents belonged to the age group of 18 to $30,25 \%$ belonged to the age group of $31-50$ and the rest $25 \%$ belonged to age group 51-80. Most of the respondents had their own houses $(85 \%)$ while a few had rented accommodation $(15 \%)$ in the entire study area. The education level of the respondents has been given in Fig. 2 while the monthly income levels of the respondent households of each of the village are provided in Table 1.

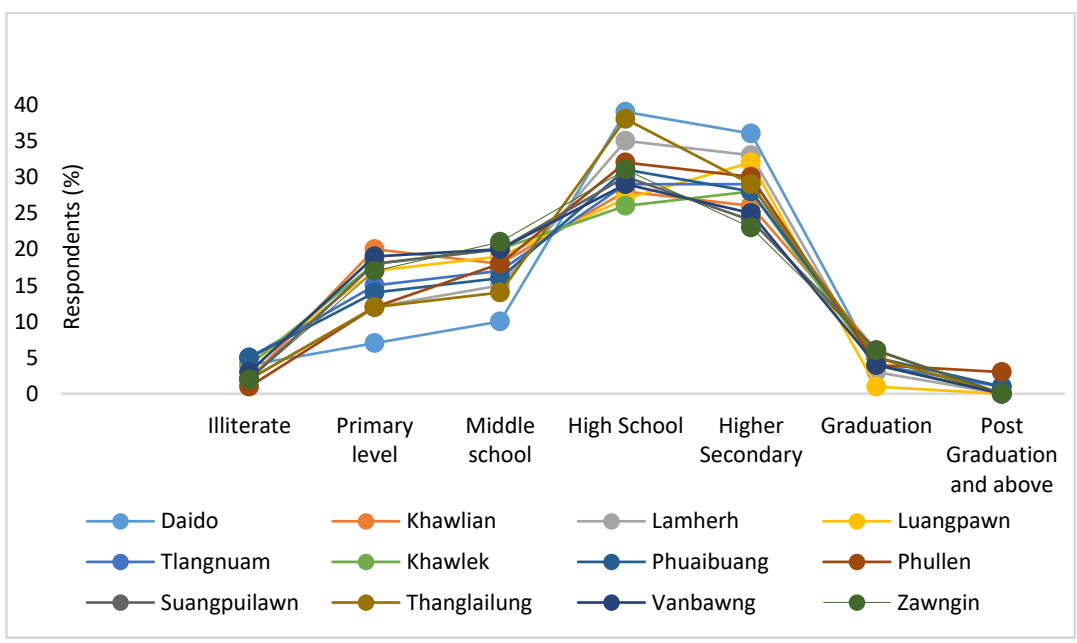

Fig. 2: Educational level of the respondents of the study area. 
Table 1: Monthly income levels of respondent households in the study area.

\begin{tabular}{|c|c|c|c|c|c|c|}
\hline \multirow[t]{2}{*}{ Sr No. } & \multirow[t]{2}{*}{ Villages } & \multirow[t]{2}{*}{ Number of Households } & \multicolumn{4}{|c|}{ Income categories in $\%$} \\
\hline & & & $<$ Rs 8,000 & Rs $8001-12,000$ & Rs $12,001-15,000$ & $>$ Rs 15,000 \\
\hline 1 & Daido & 95 & 23 & 42 & 31 & 4 \\
\hline 2 & Khawlian & 420 & 22 & 44 & 32 & 2 \\
\hline 3 & Lamherh, & 128 & 16 & 36 & 42 & 6 \\
\hline 4 & Luangpawn & 99 & 14 & 37 & 39 & 10 \\
\hline 5 & Tlangnuam & 98 & 11 & 34 & 44 & 11 \\
\hline 6 & Khawlek & 151 & 21 & 38 & 39 & 2 \\
\hline 7 & Phuaibuang & 430 & 13 & 41 & 38 & 8 \\
\hline 8 & Phullen & 460 & 8 & 31 & 49 & 12 \\
\hline 9 & Suangpuilawn & 450 & 14 & 43 & 37 & 6 \\
\hline 10 & Thanglailung & 170 & 16 & 46 & 36 & 2 \\
\hline 11 & Vanbawng & 243 & 9 & 46 & 41 & 4 \\
\hline 12 & Zawngin. & 131 & 15 & 45 & 36 & 4 \\
\hline
\end{tabular}

Source: Computed by authors based on field survey.

\section{DISCUSSION}

The study region which is part of Mizoram state has a bounty of water resources in the form of steams, rivulets, springs, and most importantly abundant rain for the greater part of the year. Ideally speaking thus, water should not be a problem in this region. However, climate change and anthropogenic activities along with lack of integrated watershed management have resulted in the water surplus regions of the Himalayan belt to water deficit region leading to serious handicap in undertaking the basic economic activities, affecting the diversity of livelihood and the drinking water sector (McPhillips 2017, Maplecroft 2011, Sharma et al. 2019, Kelly \& Adger 2000, Shrestha et al. 2019, O'Brien et al. 2004). In general, the villages of the study area, as is elsewhere in Mizoram, is most affected during the non-monsoonal season/dry season. Hence the study has been specially conducted keeping in view the water availability during the season of scarcity.

\section{Various Sources of Water in the Study Area}

In the villages of Mizoram, particularly the villages of the study area, Tuikhur or village spring source (VSS) and piped water supply constitute the main lifeline of water supply. The Piped water supply is managed by the PHED department. Other sources of water include rainwater harvested and water taken from the stream or river. Water taken from streams is mostly done by private operators depending on the demand for water by the villagers. These are the important sources of water in rural areas obtained by the villagers for their daily uses. The various water sources in the study area (Fig. 3) have been analysed briefly in the following section.
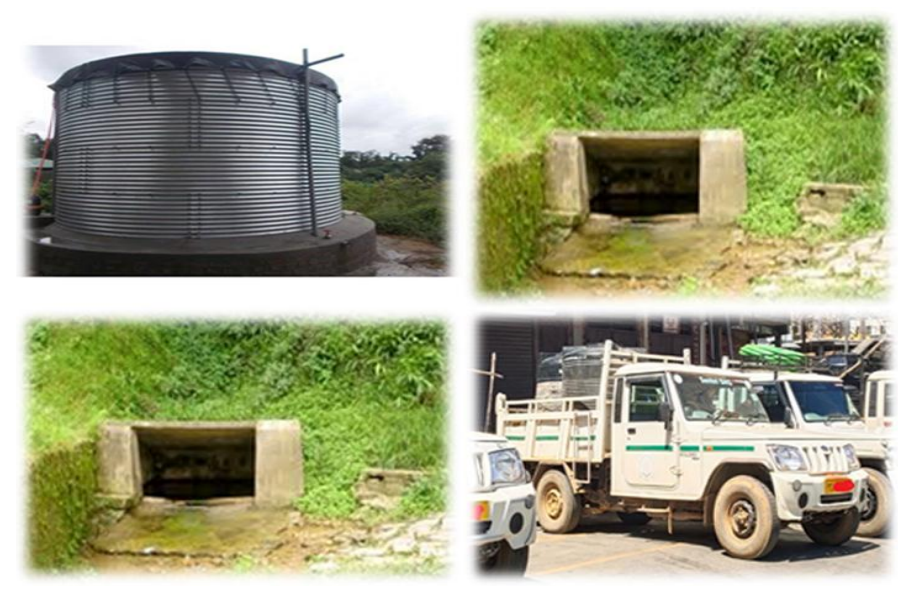

Fig 3: Sources of water supply in the study area (clockwise from top left; PHED, Tuikhur, Rainwater harvesting, private operators). 


\section{Tuikhur}

Till today, one of the most important sources of water supply in the rural areas can be considered as Tuikhur or village spring source (VSS). The villagers, especially the poor family greatly depend on Tuikhur water for their daily needs. Almost every village has access to such water sources. It is a perennial water source, however in recent times with rainfall variability and various anthropogenic reasons many of these sources either dries up or has reduced water quantity during the dry season or non-monsoonal season of Mizoram (Table 2). It is mainly used for drinking, cooking, cleaning and washing purposes. But during the scarcity of water, the villagers are prohibited from using Tuikhur water for cleaning and washing.

\section{Piped Water Supply}

Piped water supply or water connection involves drawing of water from the streams and rivers by PHED. In most of the villages, the pumping system is used for collecting water from the streams and river. The pumping system is the method of lifting water from the river or stream through high a lift pump driven by the power in which water is transported to the storage reservoir. The location of the reservoir is put at a higher elevation within the village so that distribution can also be done easily through the gravity feed system. The construction charge is generally borne by the government or sometimes by the individual Village councils. Water is hauled from the local streams/tributaries, Kawrawng, Leisang, Ramrikawn, Mauhar, Kawrte, etc. The private household connection, at Rs 300/month, given by PHED receives

Table 2: Spring water source of the study area.

\begin{tabular}{|llll|}
\hline \multirow{2}{*}{ Sr No } & Villages & \multicolumn{2}{l|}{ Springs/Tuikhurs } \\
\cline { 3 - 4 } & & Total & Perennial \\
\hline 1 & Daido & 05 & 03 \\
2 & Khawlian & 04 & 01 \\
3 & Lamherh, & 04 & 03 \\
4 & Luangpawn & 05 & 04 \\
5 & Tlangnuam & 05 & 04 \\
6 & Khawlek & 04 & 04 \\
7 & Phuaibuang & 05 & 03 \\
8 & Phullen & 07 & 03 \\
9 & Suangpuilawn & 12 & 08 \\
10 & Thanglailung & 04 & 02 \\
11 & Vanbawng & 04 & 02 \\
12 & Zawngin. & 05 & 04 \\
\hline
\end{tabular}

Source: Computed by authors based on field survey. water for about an hour per week. The total amount of water obtained is about 2,000 litres per week. Certain villages also have public water distribution points supplied by PHED, where the total amount received is about 225-300 litres/ month. The supply is highly irregular during the dry season.

\section{Rainwater}

Rainwater is harvested during the rainy season. Owing to climatic conditions the houses have sloping roofs with corrugated sheets, aiding in the collection of rainwater. The same is stored in barrels or large plastic containers. During the monsoonal season, the water is used mainly for washing purposes and watering individual kitchen gardens. Sometimes it is even used for drinking after filtering it. There is no definite data available for rainwater harvesting and water obtained from private operators. The total amount of rainwater that is stored by individual households is around 3000 litres/month. This is primarily stored for the dry months and lasts for about 2 months. The water obtained from private operators are need-based; as and when required. So far only Suangpuilawn village has utilized rainwater harvesting to a great extent.

\section{Water From Stream}

Water is pumped indiscriminately from streams or rivers during the dry season. The water is pumped into barrels or tanks of 2000 litres capacity and sold to the villagers by private operators. The price of water generally ranges from Rs 600 per 1500 litres to Rs 900 for 2000 litres.

\section{Water Supply and Management System in the Study Area}

As is observed from the preceding section, the study area does not have any fixed water supply system. It follows a 3 tier system of Public Health Engineering Department (PHED), Government of Mizoram; Village council level through the management system of Tuikhur; and private level through household rainwater harvesting and buying of water from private operators as and when the need arises. In certain villages like Suangpuilawn and Thanglailung community rainwater harvesting has been undertaken by the respective Village council on large scale for ensuring village level self-sufficiency. Water requirement, supply and management system differ quantitatively among each of the 12 villages owing to population size, water management system, the elevation of the village and monetary capacity of the residents.

\section{Households and Water Consumption Pattern}

The average amount of water available to the villages is around 2,14,248.6 gallons of water per month. This excludes 
the water obtained from private sources. Based on the total population of each village, the per head water availability was computed and is represented in Table 3. The per head water availability on an average stands at a meagre $21 \mathrm{lpcd}$ or 5.63 gallons which is much lower than the minimum service delivery of 55 lpcd or 14.52 gallons as decided by Jal Jeevan Mission, under Ministry of Water Resources, India (https://pib.gov.in). The extreme scarcity particularly in the dry season forces the population to restrict consumption, stop agricultural practices and compels the women-folk to trudge daily in search of water from distant streams/springs and buy water from private sources at a high price.

Owing to scarcity, water is used in a very controlled manner in the dry season. The excess usage like watering of plants/kitchen garden is curtailed, recycling of available water is encouraged (reusing water used for washing vegetables/clothes) and a general restriction of water usage is practised as represented in Fig. 4. With decreased water supply from various sources during the lean period, PHED water supply becomes the major source of water for the study area as represented in Fig 4. With the unavailability of a community-based rainwater harvesting system and household rainwater harvesting system owing to financial reasons, the stored rainwater does not last long. Thus the share of rainwater in meeting water demand of the study area is too meagre as observed in Fig. 4. Water obtained at a high price from private operators comes to a close second for almost all the villages barring Suangpuilawn. The village is self-reliant concerning to meeting its water demand. Almost $25 \%$ of the water need of Suangpuilawn is met through planned community based and household rainwater harvesting system. The village has 5 large water storage tanks of 3000 litres each for community rainwater harvesting (Fig 5). Eighty seven households out of 450 total households of the village, constituting about $19.33 \%$ of the total population, have individual household rainwater harvesting systems each having storage tanks of 2500 litres.

Table 3: Water availability for the study area.

\begin{tabular}{|llll|}
\hline Villages & Total population & Water availability (gallons/month) & Water availability (gallons/per head/month) \\
\hline Daido & 615 & 80942.57 & 4.39 \\
Khawlian & 2400 & 396972.6 & 5.51 \\
Lamherh & 618 & 124451.8 & 6.71 \\
Luangpawn & 478 & 96449.52 & 6.73 \\
Tlangnuam & 440 & 94204.05 & 7.14 \\
Khawlek & 769 & 135256.5 & 5.86 \\
Phuaibuang & 2500 & 365879.4 & 4.88 \\
Phullen & 2700 & 402810.8 & 4.97 \\
Suangpuilawn & 2400 & 403814.7 & 5.61 \\
Thanglailung & 980 & 150076.6 & 5.10 \\
Vanbawng & 1255 & 206741.7 & 5.49 \\
Zawngin & 740 & 113383 & 5.11 \\
\hline
\end{tabular}

Source: Computed by authors based on field survey.

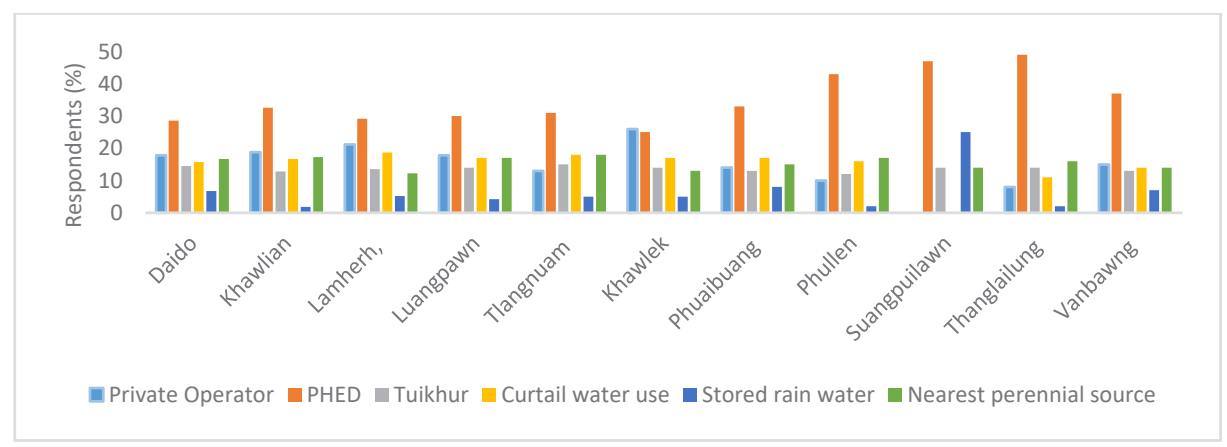

Fig. 4: Meeting water demand during the lean period for the study area. 


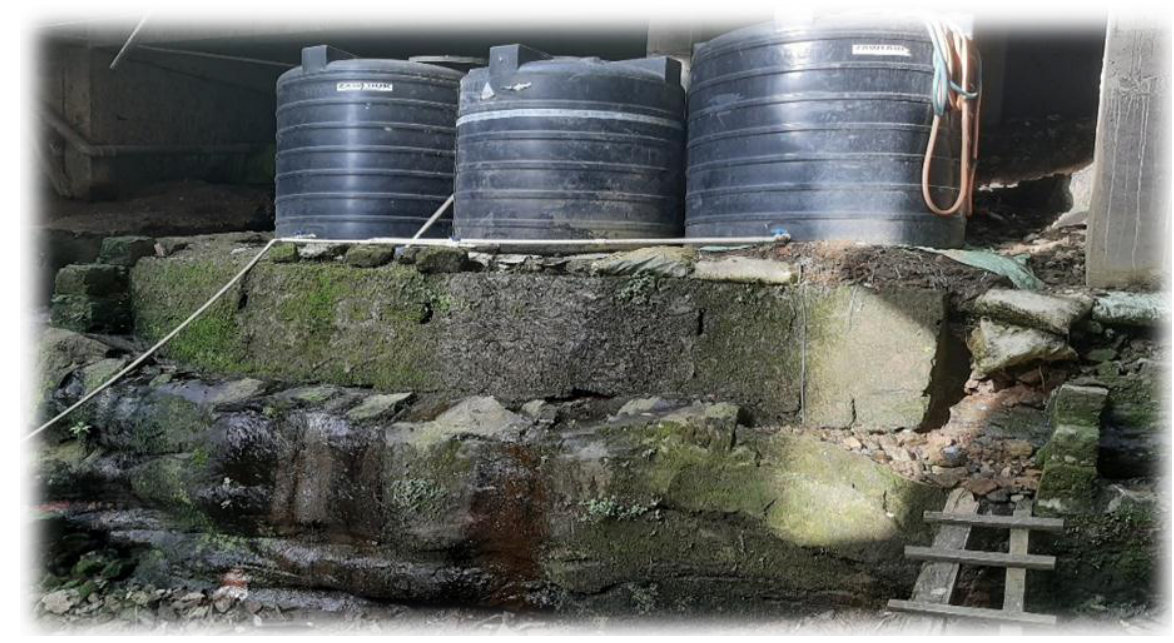

Fig 5: Community rainwater harvesting tanks of Suangpuilawn village.

\section{Demand-Supply Gap}

The average requirement of the study area is 9,43,125 litres per month or 2,49,148 gallons per month with the highest requirement from Khawlian village (4,89,776.5 gallons per month) as visible from Fig. 6 and an average supply of just $2,14,248$ gallons per month. However, the largest deficit is noticed in Phuaibuang village with a shortfall of 1,04,374.7 gallons per month of water. Suangpuilawn and Thanglailung are the only villages having NIL water deficit owing to wide-scale rainwater harvesting system and planned water management.

The total requirement of water for the entire study area is $29,89,777$ gallons of water per month. The total water supply/

Table 4: Water supply details of the study area.

\begin{tabular}{|c|c|c|c|}
\hline Village & Tuikhurs & PHED & Rain water \\
\hline & \multicolumn{3}{|c|}{ Supply in gallons/month } \\
\hline Daido & 48977.65 & 26417.29 & 5547.63 \\
\hline Khawlian & 82897.45 & 302742.1 & 11333.02 \\
\hline Lamherh & 56031.07 & 62080.63 & 6340.149 \\
\hline Luangpawn & 63559.99 & 29587.36 & 3302.161 \\
\hline Tlangnuam & 61974.96 & 19020.45 & 13208.64 \\
\hline Khawlek & 80044.38 & 45701.91 & 9510.223 \\
\hline Phuaibuang & 101442.4 & 204998.2 & 59438.9 \\
\hline Phullen & 130448.6 & 267078.8 & 5283.457 \\
\hline Suangpuilawn & 91958.58 & 254398.5 & 57457.6 \\
\hline Thanglailung & 40576.95 & 104876.6 & 4623.025 \\
\hline Vanbawng & 69900.14 & 126274.6 & 10566.91 \\
\hline Zawngin & 59755.9 & 42531.83 & 11095.26 \\
\hline
\end{tabular}

Source: Computed by authors based on field survey. availability from Tuikhurs, PHED and rainwater harvesting (including water haulage from distant streams/springs) is $25,70,983.3$ gallons of water per month as represented in Table 4. Thus there is a total deficit of 4,18,793.25 gallons of water per month. This is predominantly during the dry season. A huge part of this deficit thus has to be filled by the private operators at a hefty price.

To understand whether there is a significant difference between demand and supply of water among all the villages of the study area, a two-sample $t$-test was conducted. The statistical analysis yielded Pearson's correlation value of $98 \%$ and p-value of 0.006 , indicating a significant difference between the variables, demand and supply of water.

To statistically analyze the level of significance between the various available water sources among the various villages, ANOVA was conducted and the result is presented in Table 5. The p-value of 0.001 represents a significant difference between the various water sources and their availability among the villages.

\section{Issues and Challenges}

The key challenge of the study area is the disparity between population and water availability per capita. Tuikhurs and rainwater harvesting systems are traditional systems while the PHED system is 30-35 years old. The topography of the region hampers water haulage which is being done by Gravity feed system and pumping system, thereby increasing the infrastructural cost. All the systems are quite old and are unable to cater to the population. Renovation of storage tanks, repair of pipelines, feeder lines, and rainwater harvesting systems are lacking in the study area. The region receives abundant rainfall from May to September (average 130 days/ year) owing to its strategic location. One of the works of 
Table 5: ANOVA test for various available water sources among the villages.

\begin{tabular}{|llllll|}
\hline ANOVA & & & & & \\
\hline Source of Variation & SS & df & MS & F & P-value \\
\hline Between Groups & 992000000000 & 2 & 496000000000 & 8.547011 & 0.001 \\
Within Groups & 1920000000000 & 33 & 58000000000 & & \\
Total & 2910000000000 & 35 & & & \\
\hline
\end{tabular}

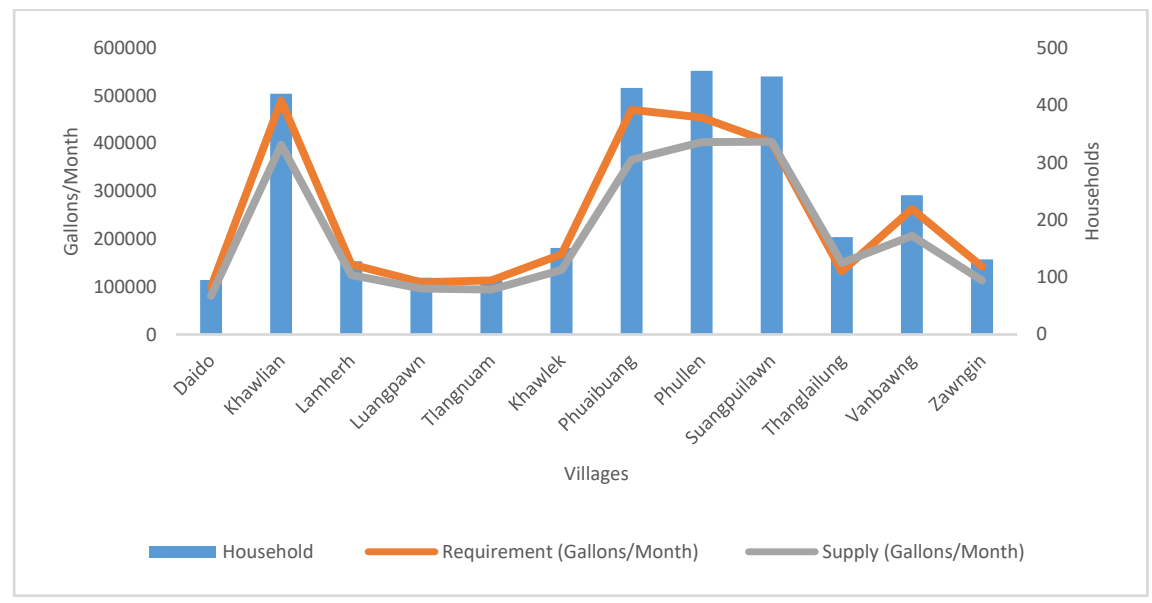

Fig 6: Demand and supply of water resource along with the number of households in each village.

PHED, Government of Mizoram is to undertake rainwater harvesting scheme, under various centrally (Government of India) sponsored schemes. Under this scheme, PHED must construct 7500 litres of storage tank for a family of 6 members for water availability of 10 lpcd for 120 days of the dry season. However, not a single such structure was found in any of the villages of the study area. In the absence of impounding of rainwater, which is to the extent of about $250-270 \mathrm{~cm}$ of annual average rainfall, the scope of catchment recharge of the dying and dried up springs/Tuikhurs and availability of water in dry season through individual/community rainwater harvesting is wasted and lost. Such anthropogenic callousness also induces environmental threats like soil erosion, run-off and increased instances of rainfall-induced landslides owing to slope instability triggered by enhanced run-off along the steep down slopes. Further, most of the villages do not have all-weather roads which hinder access to the surrounding rivers/streams (Tuivai river and Tuivawl river).

\section{CONCLUSION}

The study region is blessed with very heavy rainfall at an annual average of $250 \mathrm{~cm}$ to $270 \mathrm{~cm}$. This is one of the highest in India. Owing to its mountainous terrain it has a plethora of water resources in the form of various streams, springs (locally called Tuikhurs) and a huge potential from rainwater harvesting system. Tuikhur forms the main lifeline of the study area encompassing 12 villages of Phullen RD block of Aizawl district, Mizoram. However, during the dry seasons, almost $50 \%$ of Tuikhurs in each of the villages dry up owing to lack of spring shed management. Thus, the water resources of the study area face a huge demand-supply gap particularly in the dry season (winter season) and are unable to meet the basic per capita water requirement of $55 \mathrm{lpcd}$ as decided by Jal Jeevan Mission, under Ministry of Water Resources, India. The per capita water availability on an average stands at a meagre $21 \mathrm{lpcd}$. The short-fall is met by buying water from private operators at a very hefty price. Further, lack of all-weather roads hinders accessibility to the surrounding rivers/streams. The dearth of proper planning is one of the reasons for this huge demand-supply gap which is proved by the self -dependency of Suangpuilawn village with regard to the water resource. Proper management of spring shed and rainwater harvesting system has made this village self-sufficient in water needs throughout the year. The only way forward for the study region is to utilize and plan its already existing resource-rainfall, in such a way as to enhance spring shed management cum recharge, impounding of rainfall by constructing various water ponds and proper rainwater harvesting system both at the community level and household level.

The present study provides a grassroots level diagnosis of the present situation of the villages of Aizawl district. 
However, one can find the same picture throughout the villages of the state as well as the other Himalayan states. As such studies like this will provide the pre-requisite groundlevel data for further integrated water resource planning.

Spring shed management through rainwater harvesting is not a new concept in India. In Sikkim, through Dhara Vikas, an atlas of 700 springs have been created along with the rejuvenation of springs. Such initiatives have also been taken in Uttarakhand.

Taking cognizance of the gravity of the situation in this region of bounty yet scarcity of water resource, various stakeholders both at the government level and NGOs along with the academic body must take part in ensuring the basic need of humanity through proper planning.

\section{REFERENCES}

Banerjee, S., Mukherjee, A., Sattar, A. and Biswas, B. 2015. Change detection of annual temperature and rainfall in Kalimpong station under hill zone of West Bengal. Indian Journal of Hill Farming, 28(2): 81-84.

Biswas, B., Jadhav, R. and Tikone, N. 2019. Rainfall distribution and trend analysis for upper Godavari basin, India, from 100 Years Record (19112010). Journal of the Indian Society of Remote Sensing, 47(10): 17811792. https://doi.org/10.1007/s12524-019-01011-8

Gupta, A. and Kulkarni, H. 2018. Report of the NITI Aayog Working Group on Inventory and Revival of springs in Himalayas for Water Security as Part of Initiatives on Sustainable Development of Mountains of Indian Himalayan Region. Submitted to NITI Aayog, Government of India.

Huq, N., Hugé, J., Boon, E. and Gain, A.K. 2015. Climate change impacts in agricultural communities in rural areas of coastal Bangladesh: a tale of many stories. Sustainable, 7: 8438-8460. https://doi.org/10.3390/ su707 8437.

Kelly, P.M. and Adger, W.N. 2000. Theory and practice in assessing vulnerability to climate change and facilitating adaptation. Clim. Change, 47: 325-352.

Kinouchi, T., Nakajima, T., Mendoza, J., Fuchs, P. and Asaoka, Y. 2019. Water security in high mountain cities of the Andes under a growing population and climate change: a case study of La Paz and El Alto, Bolivia. Water Secur., 6: 100025.
Kuchimanchi, B.R., Nazareth, D., Bendapudi, R., Awasthi, S. and D'Souza, M. 2019. Assessing differential vulnerability of communities in the agrarian context in two districts of Maharashtra, India. Clim. Dev., 11(10): 918-929. https://doi.org/10.1080/17565 529.2019.1593815.

Kumar, D.N. 2017. Water management in India: The multiplicity of views and solutions. International Journal of Water Resources Development, 34(1): 1-15. doi: 10.1080/07900627.2017.1351333.

Magadza, C.H.D. 2000. Climate change impacts and human settlements in Africa: Prospects for adaptation. Environ. Monit. Assess., 61: 193-205.

Maplecroft, 2011. Climate Change Rist Atlas 2010, Vulnerable Nations and Safe Havens.

McPhillips, D. 2017. 10 Countries with the Worst Water Supply. U. S. News and World Report.

MoWR 2012. National Water Policy 2012. Ministry of Water Resources, Government of India, Delhi. Available at: http://mowr.gov.in/sites/ default/files/NWP2012Eng6495132651_1.pdf.

MoWR 2002. National Water Policy. Ministry of Water Resources, Government of India, Delhi.

Mukherji, A., Molden, D., Nepal, S., Rasul, G. and Wagnon, P. 2015. Himalayan waters at the crossroads: issues and challenges. International Journal of Water Resources Development 31(2): 151160. doi:10.1080/07900627.2015.1040871.

O’Brien, K., Leichenko, R., Kelkar, U., Venema, H., Aandahl, G., Tompkins, H., Javed, A., Bhadwal, S., Barg, S., Nygaard, L. and West, J. 2004. Mapping vulnerability to multiple stressors: climate change and globalization in India. Glob. Environ. Chang., 14: $303-$ 313. https://doi.org/10.1016/j.gloen vcha.2004.01.001.

Ramprasad, V. 2018. Debt and vulnerability: indebtedness, institutions and smallholder agriculture in South India. J. Peasant Stud., 0: 1-22. https://doi.org/10.1080/03066 150.2018.1460597.

Sharma, E., Molden, D., Rahman, A., Khatiwada, Y.R., Zhang, L., Singh, S.P., Yao, T. and Wester P. 2019. The Hindu Kush Himalaya Assessment. Springer Int. Publ. https://doi.org/10.1007/978-3-31992288-1.

Shrestha, R.P., Pasakhala, B. and Qasim, S. 2019. Assessing household vulnerability to climate variability in far-west Nepal. Nature, 12: 83-118.

Snyder A. 2014. Shortage in the Mountains of Plenty: Water Supply in Mountain and Hill Cities Throughout the Hindu-Kush Himalayan Region, ICIMOD and The World Food Prize. Available at: https:// www.worldfoodprize.org/documents/filelibrary/images/youth_ programs/2014_interns/2014_br_research_papers/SnyderAbigail_ LONGReport_56ED38F157B76.pdf. 